\title{
Evaluation of Lead and Copper content in hair of workers from oil product distribution companies in Iraq
}

\author{
Ausama Ayob Jaccob®1 \\ ${ }^{1}$ Department of Pharmacology and Toxicology, College of Pharmacy, University of Basrah, Basrah, Iraq
}

\begin{abstract}
Serious health consequences can occur not only from acute exposure to environmental toxicants, but also from chronic exposures to minute quantities. Petroleum substances are widely distributed and used in huge amount, mainly as fuels. A total number of 45 males aged between 20 and 45 years participated in this study. The participants were divided in to two groups: The first group of 25 subjects worked at least 8hours/day in different oil product distribution companies in both Basrah and Thiqar Governorates-Iraq. The second group (control group) of 20 healthy individuals with age and weight matched with the test group and lived far away from hazardous exposure. Heavy metals levels in hair were measured by Atomic Absorption Spectrophotometer. Statistical analysis was performed using GraphPad Prism (version 6.0). Higher levels of lead and cupper were observed in the hair of subjects working in different oil product distribution companies compared to control group. Heavy metals evaluation in hair samples could be used as a good bioindicator of heavy metal exposure in occupational and environmental surveys for various populations for screening for heavy metals toxicity. In the present study high levels of heavy metals were observed in workers at different oil product distribution companies in Iraq.
\end{abstract}

Keywords: Fuel. Heavy metals/effects. Hair. Pollutions.

\section{INTRODUCTION}

Nowadays, it is clearly known that serious health consequences can occur not only from acute exposure to environmental toxicants, but also from chronic exposures to diminutive quantities. Such exposures and their adverse outcomes are often insidious, in particular at an individual level (Reis et al., 2007). Heavy metals pollution is one of the most serious hazard to the natural environment due to their potent toxicity, persistence, absorption and accumulation which is faster than detoxification (Wang et al., 2009). Petroleum substances are widely distributed and used in bulky quantities, mainly as fuels. These fuels are complex mixtures of numerous ingredients. According to PETROTOX and PETRORISK spreadsheet models that designed to facilitate the performance of hazard and risk assessments of petroleum substances, the primary ingredients that are responsible for danger health consequences are hydrocarbons, in addition to heavy metals. Humans are exposed to lead $(\mathrm{Pb})$ through dust and vapor via

Correspondence: A. A. Jaccob. Department of Pharmacology and Toxicology, College of Pharmacy, University of Basrah, Basrah, Iraq. E-mail: ausama1979@yahoo.com / ausamaphd@gmail.com several routes from different sources (Reis et al., 2007; Wang et al., 2009). Anthropogenic sources like fossil fuel combustion (petroleum, coal and natural gas), smelting industries and waste incineration have been considered the major source of environmental bioaccumulation and persistence of $\mathrm{Pb}$ and copper $(\mathrm{Cu})$ (Pan, Wang, 2012). Air and water are the major sources for lead exposure while soil surface and plants are the most sink for airborne lead through processing industry that in turn through air dusting contaminates drinking water, surface water, ground waters and rivers. (Kennedy et al., 2016; Jaleel, Noreen, Baseer, 2001).

Hair had been used as biological indicator as well as nail and blood for environmental and occupational health assessment and for evaluating extent of previous exposure (Cho, 1997). In addition, chemical analysis of hair samples can be utilized to establish a record of the past exposure of people to contaminants for monitoring environmental changes that affect people (Rasmussen et al., 2008). Lead is a toxic element that have various unfavorable physiologic effects on human, like hemoglobin synthesis inhibition, hypertension, kidney and brain damage plus impact on reproduction in male and female (Castellino, Castellino, Sannolo, 1997). 
Copper is a vital dietary nutrient like an essential trace minerals that act as a cofactor for many important enzymes for physical and mental health. But due to wide spread occurrence of copper this increases chances of overexposure leading to neurotic symptoms like affective disorder (Ashish, Neeti, Himanshu, 2013; Nastoulis et al., 2017). Both copper and lead are harmful in highly exposed individuals, but copper is much less toxic, it has been shown that elevated levels of copper for 14 days or more can cause nausea, vomiting, diarrhea and permanent organs damage (Andrade, Aschner, Marreilha, 2017).

Continuous exposure of workers to vapor of an oil product in different distribution companies caused hundreds of workers to be hospitalized seeking for medical treatment for acute and chronic diseases. Therefore, the present study was designed to evaluate the levels of heavy metals in hair of workers as a possible bioindicator of the primary causes of progressive deterioration of workers.

\section{MATERIAL AND METHODS}

\section{Subjects}

A total number of 45 males aged 20 between and 45 years participated in this study. The study was conducted from January 2015 to June 2015 at Department of pharmacology and toxicology, College of Pharmacy, University of Basrah, Basrah, Iraq.

The participants were divided in to two groups: The first group was test group that consisted of 25 subjects each worked at least $8 \mathrm{~h} /$ day in different oil product distribution companies in both Basra and Thiqar Governorates-Iraq. The second group was the control which consisted of 20 healthy individuals living far from hazardous exposure and with age and weight matching the test group. The purpose of the study was explained to the participants all signed the consent form. The protocol was approved by Local Ethical Committee of college of pharmacy, Basrah University. Exclusion criteria were shown in Table I.

TABLE I - Exclusion criteria

Exclusion criteria

Patients with history of chronic diseases

Subjects who had undergone significant physiologic stress (surgery, fever, etc)

Individuals who received treatment for chronic diseases

Individuals who received tonics and minerals

Smoking individuals

\section{Preparation of hair samples}

Approximately $0.5 \mathrm{~g}$ of hair sample was cut with thin-blade stainless steel scissors. Hair samples range between 1 to $2 \mathrm{~cm}$ lengths near scalp area were collected, washed with liquid soap, rinsed with de ionized water to remove dirt's, and then dried. Subsequently samples were accurately weighed to $0.2 \mathrm{~g}$. Then hair samples were prepared for the wet digestion procedure.

The $\mathrm{Cu}$ and $\mathrm{Pb}$ in hair samples must be released firstly from the binding protein matrix using wet digestion method and then measured by Atomic Absorption Spectrophotometer (Buck Model 211-VGP).

\section{Digestion method}

In a clean vessel, $0.2 \mathrm{~g}$ of hair was mixed with $1.5 \mathrm{~mL}$ $\mathrm{HNO}_{3}: 0.5 \mathrm{~mL} \mathrm{HClO}_{4}$. The vessel was heated on hot plate at $100{ }^{\circ} \mathrm{C}$ for $20 \mathrm{~min}$ and then diluted with distilled water to a final volume of $5 \mathrm{~mL}$, and stored for later analysis.

\section{Estimation of $\mathrm{Cu}$ and $\mathrm{Pb}$ levels}

Heavy metals levels were estimated by Atomic Absorption Spectrophotometer. According to the manufacturer, the flame conditions were fixed and standard solutions for both $\mathrm{Cu}$ and $\mathrm{Pb}$ were prepared and aspirated to calibrate the instrument. Three concentrations of standards for each element (depending on samples levels of both elements overriding upper and lower limits) were prepared using 1000 ppm STD supplied by Buck company, and their absorbency's were measured and calibration curves were auto executed by the software of the instrument. The analytical method was evaluated by adding known concentrations of standard solutions to initial measured concentrations of $\mathrm{Cu}$ and $\mathrm{Pb}$. It showed excellent correlation between major/minor values ranging from $0.7 \%$ to $3.2 \%$ exemplifying the high precision of the instrument and accuracy of the experiment. To obtain more accurate data, the regression coefficient of the prepared standard calibration curves for $\mathrm{Cu}$ and $\mathrm{Pb}$ were made to be greater than 0.99 to obtain more sensitive results and linear check.

The method used for the analysis of $\mathrm{Pb}$ and $\mathrm{Cu}$ were based on operator's manual (February 2005 VER 3.94 C by Analyst: Gerald J. De Menna), the detection limits were identified as the lowest concentration given a detectable absorbance above the noise range with values of $0.005 \mathrm{ppm}$ for $\mathrm{Cu}$ at wave length $324.8 \mathrm{~nm}$, and $0.4 \mathrm{ppm}$ for $\mathrm{Pb}$ at wave length $217 \mathrm{~nm}$. From the prepared standard curves the unknown concentrations of elements were calculated using the following equation: 
[Sample concentration $=$ Read concentration $\times$ dilution factor]

\section{Statistical analysis}

Values were expressed as mean \pm SD. Level of significant difference between the control and tested groups was determined using the unpaired t-test. Correlation analysis were achieved using GraphPad Prism software for windows (version 6.0).

\section{RESULTS}

Determination of heavy metals concentrations in hair samples by Atomic Absorption gave an idea about the potential previous long-term heavy metal exposure and accumulation. A higher level of lead $(31.64 \pm 3.8 \mu \mathrm{g} / \mathrm{g})$ was observed in hair of workers in different oil product distribution companies compared to control group $(19.1 \pm 1.09 \mu \mathrm{g} / \mathrm{g})$ as shown in Figure1.

Figure 2 shows a 2 fold significant increase in hair copper concentration between occupationally exposed oil product distribution workers $(69.6 \pm 15.7 \mu \mathrm{g} / \mathrm{g})$ and nonexposed individuals $(36.8 \pm 1.5 \mu \mathrm{g} / \mathrm{g})$.

Table II illustrates the median levels of copper and lead in hair of normal individuals in different countries and in Iraq . The highest mean levels of copper and lead was observed in workers from southern Iraq and also in the control group compared to the rest of the countries.

Figure 3 and 4 illustrate the correlation analysis of heavy metals of copper and lead in both worker and control groups. There was no correlation observed $(\mathrm{R}=0.1386)$ between copper and lead in workers group. Regarding correlation analysis between $\mathrm{Cu}$ and Lead in normal control group, the same finding was obtained $(\mathrm{R}=0.1076)$.

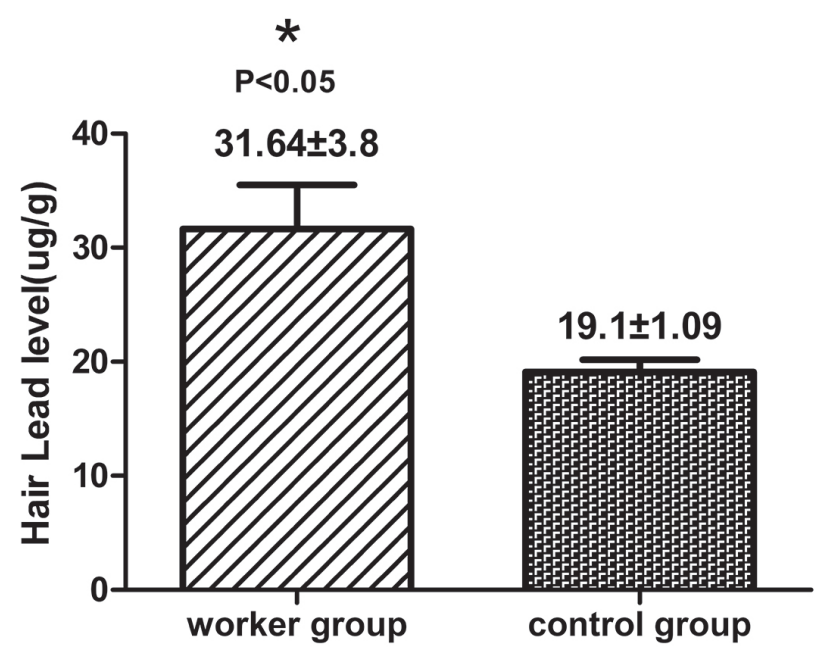

FIGURE 1 - $\mathrm{Pb}$ concentrations in hair of workers in different oil companies. Values were expressed as mean $\pm \mathrm{SD}$; * represents a significant difference with $\mathrm{P}>0.01$.

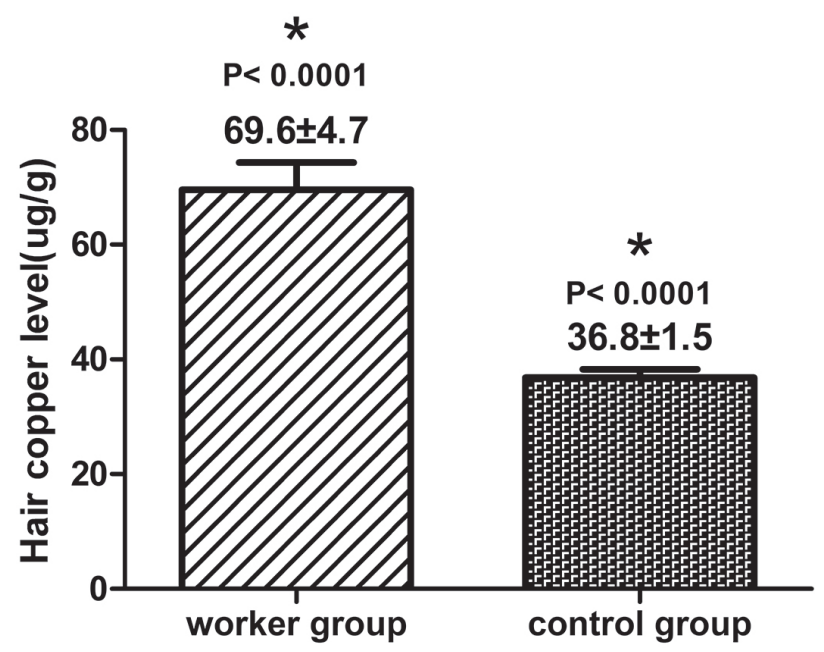

FIGURE 2 - $\mathrm{Cu}$ concentrations in hair of workers from different oil distribution product companies. Values were expressed as mean $\pm \mathrm{SD}, *$ represents a significant difference with $\mathrm{P}>0.01$.

TABLE II - Median levels of $\mathrm{Pb}$ and $\mathrm{Cu}$ in hair of peoples living in different countries compared to median levels in Iraq

\begin{tabular}{lccc}
\hline \multirow{2}{*}{ Country } & \multicolumn{2}{c}{ Median metals level $(\boldsymbol{\mu g} / \mathbf{g})$} & References \\
\cline { 2 - 3 } & $\mathbf{P b}$ & $\mathbf{C u}$ & (He et al., 2016) \\
China & 3.9 & 23.9 & (Sreenivasa et al., 2002) \\
India & 5 & 16 & (Rezza et al., 2018) \\
Italy & 1.03 & 18.5 & (Pragst et al., 2017) \\
South Soudan & 9.3 & & (Skalny et al., 2015) \\
Russia & 1.04 & & (Kolachi et al., 2011; Kazi et al., 2014) \\
Pakistan & 8.18 & 12.8 & (Llorente, Navarro, Izquierdo, 2017) \\
Spain & 0.5 & 28.6 & (Szynkowska et al., 2015) \\
Poland & 1.15 & 5.8 & Present study \\
South Iraq (worker) & 31.6 & 69.6 & Present study \\
South Iraq (control) & 9.1 & 36.8 &
\end{tabular}




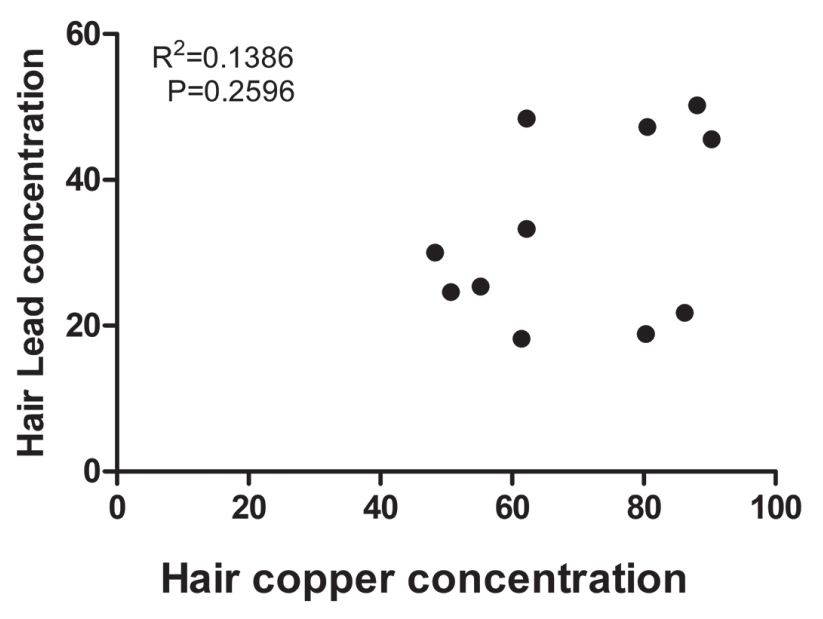

FIGURE 3 - Correlation analysis of copper and lead levels in workers at different oil distribution companies.

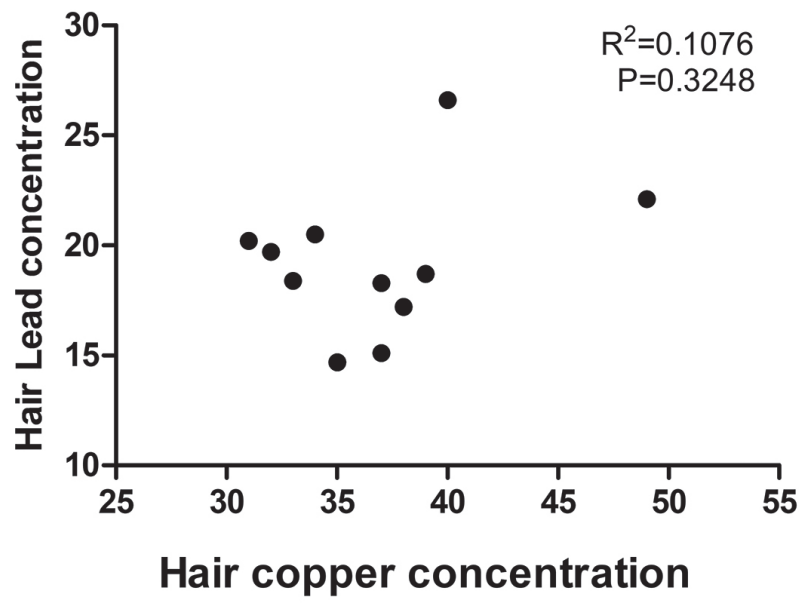

FIGURE 4 - Correlation analysis of copper and lead levels in normal control individuals.

\section{DISCUSSION}

The mean level of determined elements $(\mathrm{Pb}$ and $\mathrm{Cu}$ ) in hair samples collected from individuals working in oil product distribution companies was higher than those from normal individuals living far from oil product companies. This reflects a possible high concentrations of pollutants in the environment (air, water, and soil), thus resulting in occupational exposure. The fuel combustion (petroleum, coal and natural gas), smelting industries and waste incineration are considered the major source of heavy metals persistence especially $\mathrm{Pb}$ and $\mathrm{Cu}$ that cause serious problems to ecosystem (Singh et al., 2011). Air, Water, plant and soil surface play a role in human heavy metal toxicity through several routes including ingestion, inhalation and direct skin exposure (Kennedy et al., 2015; Farsam, Zand, 1991). $\mathrm{Cu}$ and $\mathrm{Pb}$ exist in high concentrations in oil product that lead to toxicity. This disturbing levels of heavy metals found in the petroleum products possess significant pollution and health risk problems to the local population and environment. The fuel combustion cause liberation and spillage of metals into the environment and water that could threaten the existence of the local population and could be deleterious to the ecosystem and aquatic life (Pulles et al., 2012).

Various biological samples such as blood, urine, hair and nails had been used for heavy metals analysis. In the present study hair selection as an accurate biological sample was evidence based and have many attractive advantages compared with other biological samples. Hair analysis considered as a non-invasive monitoring method used to measure occupational and environmental exposure for toxicity in the population. Hair is composed mainly of keratin, which is a protein that can bind to various metals and is considered as a storage part. In addition melanin pigments can bind to cations by ionic interaction at physiological pH (Chlopicka et al., 1998; McLean et al., 2009). . Hair is highly stable simple to transport and metals concentrations are higher in hair compared to other tissues and fluids. Furthermore, human hair allows long-term monitoring due to slow growth rate of approximately $1 \mathrm{~cm}$ per month (Moreda-Piñeiro et al., 2007). Hair analysis as an indicator of the area of residence and levels of toxicity of metals in hair are generally accepted as positive parameters of health risk and environmental pollution (Gil, Hernández, 2015).

Therefore, the exposure of the local population to heavy metals deserves future attention.

Chronic exposure to heavy metals can affect health and may lead to development of chronic and acute diseases. Lead for example can inhibit enzymes that involve in various physiologic functions including hemoglobin synthesis and erythroblast growth resulting in damage of kidneys, reproductive system, brain, nervous system and red blood cells (White, 1975; Castellino, Castellino, Sannolo, 1997). On the other hand copper is an essential element that is vitally important for mental and physical health mainly as co factor, but due to widespread occurrence, the chances of copper toxicity is high (Ashish, Neeti, Himanshu, 2013). All these factors may explain frequent hospitalization and endocrine disorder of individual working in contaminated locations.

The present study revealed that, there were significant levels of both lead and copper in hair of workers at different oil product distribution companies compared to control group. This reflects higher rate of exposure to toxic metals and higher incidence of pollutions of oil product distribution workers. Workers might be exposed to toxic metals through different routes. Khudzari et al reported that high level of heavy metals in hair of sanitation workers 
or people living nearby compared to people living far from hazardous waste sites (Khudzari et al., 2013). Our findings correlate with Khudzari's group findings.

The results are consistent with that previously reported by Al-Rudainy (2010) from Basrah city and by AlShamri et al. (2010) from Najaf city in Iraq They found significant elevation in blood lead levels in workers from different factories. In addition, Bahrami et al (2002) found a significant elevation of blood lead in the fuel stations worker in Hamadan City of Iran nearby Basra city. The highest blood lead concentration was found in the fuel stations workers with more than 14 years of exposure. This is consistent with the fact that duration of exposure to leaded fuel was significantly correlated with the blood lead level reported previously (Schafer et al., 2005). In another study conducted in Karachi city of Pakistan, blood lead in petrol- pump workers was found to be not significantly higher compared to normal control (Yakub et al., 2009).

\section{CONCLUSION}

1. Our data showed that $\mathrm{Cu}$ and $\mathrm{Pb}$ in hair could be used as an indicator of heavy metal exposure in occupational and environmental surveys for various populations

2. Lead and copper concentrations in hair were significantly increased in oil station workers compared to normal individuals living in Basrah city far away from hazardous contaminants

3. The workers in oil stations or petrol stations and refiner were exposed frequently to high levels of heavy metals that may be the cause of frequent illness.

\section{ACKNOWLEDGMENTS}

The author thanks University of Basrah, college of pharmacy for scientific support and continuous encouragement. Also we thank Dr. Sihem Aouabdi from Science Edit For The Developing World who corrected the English language of the paper.

\section{REFERENCES}

Al-Rudainy LA. Blood lead level among fuel station workers. Oman Med J. 2010;25(3):208-211.

Al-Shamri AMJ, Nama RD, Radhi AW, Odda FM. Determination of lead, copper, iron, and zinc in blood of fuel station worker at Al-Najaf city. Iraqi Acad Scientic J. 2010;1-10.
Andrade VM, Aschner M, Marreilha Dos Santos AP. Neurotoxicity of metal mixtures. Adv Neurobiol. 2017;18:227265.

Ashish B, Neeti K, Himanshu, K. Copper toxicity: a comprehensive study. Res J Recent Sci. 2013;2:58-67.

Bahrami AR, Mahjub H, Assari MJ. A Study of the relationship between ambient lead and blood lead .among gasoline-station workers. Iranian J Publ Health. 2002;31(3-4):92-95.

Castellino N, Castellino P and Sannolo N. Inorganic lead exposure: metabolism and intoxication. Am J Epidemiol. 1997;145(4):382.

Chlopicka J, Zachwieja Z, Zagrodzki P, Frydrych J, Slota P, Krosniak M. Lead and cadmium in the hair and blood of children from a highly industrial area in Poland. Biol. Trace Elem Res. 1998;62(3):229-234.

Cho SY. Trace element exposure in man by instrumental neutron activation analysis of hair. J Radio Anal Nucl Chem. 1997;217(1):107-109.

Farsam H, Zand N. A preliminary study of lead deposition on plant leaves n Tehran. Iran J Publ Health. 1991;20(14):27-34.

Gil F, Hernández AF. Toxicological importance of human biomonitoring of metallic and metalloid elements in different biological samples. Food Chem Toxicol. 2015;80:287-97.

He MJ, Wei SQ, Sun YX, Yang T, Li Q, Wang DX. Levels of five metals in male hair from urban and rural areas of Chongqing, China. Environ Sci Pollut Res Int. 2016;23(21):22163-22171.

Jaleel MA, Noreen R, Baseer A. Concentration of heavy metals in drinking water of different localities in district east Karachi. J Ayub Med Coll Abbottabad. 2001;13(4):12-5.

Kazi TG, Shah F, Shaikh HR, Afridi HI, Shah A, Naeemullah Arain SS. Exposure of lead to mothers and their new born infants, residents of industrial and domestic areas of Pakistan. Environ Sci Pollut Res. 2014;21(4):3021-3030.

Kennedy C, Lordo R, Sucosky MS, Boehm R, Brown MJ. Evaluating the effectiveness of state specific lead-based paint hazard risk reduction laws in preventing recurring incidences of lead poisoning in children. Int J Hyg Environ Health. 2016;219(1):110-7. 
Khudzari JM, Wagiran H, Hossain I, Ibrahim N. Screening heavy metals levels in hair of sanitation workers by X-ray fluorescence analysis. J Environ Radioact. 2013;115:1-5.

Kolachi NF, Kazi TG, Afridi HI, Kazi N, Kandhro GA, Shah $\mathrm{AQ}$, et al. Distribution of copper, iron, and zinc in biological samples (scalp hair, serum, blood, and urine) of Pakistani viral hepatitis (A-E) patients and controls. Biol Trace Elem Res. 2011;143(1):116-130.

Llorente Ballesteros MT, Navarro Serrano I, Izquierdo Álvarez S. Reference levels of trace elements in hair samples from children and adolescents in Madrid, Spain. J Trace Elem Med Biol. 2017;43:113-120.

McLean CM, Koller CE, Rodger JC, MacFarlane GR. Mammalian hair as an accumulative bioindicator of metal bioavailability in Australian terrestrial environments. Sci Total Environ. 2009;407(11):3588-3596.

Moreda-Piñeiro J, Alonso-Rodríguez E, López-Mahía P, Muniategui-Lorenzo S, Prada-Rodríguez D, Moreda-Piñeiro A, et al. Determination of major and trace elements in human scalp hair by pressurized-liquid extraction with acetic acid and inductively coupled plasma-optical-emission spectrometry. Anal Bioanal Chem. 2007;388(2):441-449.

Nastoulis E, Karakasi MV, Couvaris CM, Kapetanakis S, Fiska A, Pavlidis P. Greenish-blue gastric content: Literature review and case report on acute copper sulphate poisoning. Forensic Sci Rev. 2017;29(1):77-91.

Pan K, Wang WX. Trace metal contamination in estuarine and coastal environments in China. Sci Total Environ. 2012;421422:3-16.

Pragst F, Stieglitz K, Runge H, Runow KD, Quig D, Osborne $\mathrm{R}$, et al. High concentrations of lead and barium in hair of the rural population caused by water pollution in the Thar Jath oilfields in South Sudan. Forensic Sci Int. 2017;274:99-106.

Pulles T, van der Gon HD, Appelman W, Marc Verheul M. Emission factors for heavy metals from diesel and petrol used in European vehicles. Atmospheric Environ. 2012;61:641-65.

Rasmussen KL, Boldsen JL, Kristensen HK, Skytte L, Hansen KL, Mølholm L, et al. Mercury levels in Danish Medieval human bones. J Archaeol Sci. 2008;35(8):2295-2306.
Reis MF, Sampaio C, Brantes A, Aniceto P, Melim M, Cardoso $\mathrm{L}$, et al. Human exposure to heavy metals in the vicinity of Portuguese solid waste incinerators e part 3: biomonitoring of $\mathrm{Pb}$ in blood of children under the age of 6 years. Int J Hyg Environ Health. 2007;210(3-4):455-459.

Rezza C, Stefano Albanese S, Ayusob R, Lima A, Jaana Sorvari $\mathrm{J}$, De Vivo B. Geochemical and $\mathrm{Pb}$ isotopic characterization of soil, groundwater, human hair, and corn samples from the Domizio Flegreo and Agro Aversano area (Campania region, Italy). J Geochem Explorat. 2018;184(Part B):318-332.

Schafer JH, Glass TA, Bressler J, Todd AC, Schwartz BS. Blood lead is a predictor of homocysteine levels in a population-based study of older adults. Environ Health Perspect. 2005;113(1):3135 .

Singh R, Gautam N, Mishra A, Gupta R. Heavy metals and living systems: An overview. Indian J Pharmacol. 2011;43(3):246-253.

Skalny AV Skalnaya MG, Tinkov AA, Serebryansky EP, Demidov VA, Lobanova YN, et al. Reference values of hair toxic trace elements content in occupationally non-exposed Russian population. Environ Toxicol Pharmacol. 2015;40(1):18-21.

Sreenivasa Raob K, Balajib T, Prasada Raoc T, Babud Y, Naidu GRK. Determination of iron, cobalt, nickel, manganese, zinc, copper, cadmium and lead in human hair by inductively coupled plasmaatomic emission spectrometry. Spectrochimica Acta Part B Atomic Spectroscopy. 2002;57(8):1333-1338.

Szynkowska MI, Marcinek M, Pawlaczyk A, Albińska J. Human hair analysis in relation to similar environmental andoccupational exposure. Environ Toxicol Pharmacol. 2015;40(2):402-408.

Wang T, Fu J, Wang Y, Liao C, Tao Y, Jiang G. Use of scalp hair as indicator of human exposure to heavy metals in an electronic waste recycling area. Environ Pollut. 2009;157(8-9):2445-2451.

White JM. Lead and haemoglobin synthesis: a review. Postgrad Med J. 1975;51(601):755-756.

Yakub M, Iqbal MP, Ali NM, Haider G, Azam I. Blood lead and plasma homocysteine in petrol pump workers in Karachi: role of vitamins B6, B12, folate and C. J Chem Soc Pak. 2009;31(2):319-323.

Received for publication on $24^{\text {th }}$ January 2018 Accepted for publication on $03^{\text {rd }}$ August 2018 